2016

\title{
Who Has Benefited Financially from Investment Treaty Arbitration? An Evaluation of the Size and Wealth of Claimants
}

\author{
Gus Van Harten \\ Osgoode Hall Law School of York University, gvanharten@osgoode.yorku.ca
}

Follow this and additional works at: http:// digitalcommons.osgoode.yorku.ca/olsrps

Part of the Dispute Resolution and Arbitration Commons

\section{Recommended Citation}

Van Harten, Gus, "Who Has Benefited Financially from Investment Treaty Arbitration? An Evaluation of the Size and Wealth of Claimants" (2016). Osgoode Legal Studies Research Paper Series. 135.

http://digitalcommons.osgoode.yorku.ca/olsrps/135 
Osgoode Legal Studies Research Paper No. 14

Vol. 12/ Issue. 3/ (2016)

\title{
Who has benefited financially from investment treaty arbitration? An evaluation of the size and wealth of claimants
}

\author{
Gus Van Harten \\ Pavel Malysheuski
}

\begin{abstract}
:
We collected data on the size and wealth of the foreign investors that have brought claims and received compensation due to ISDS. Our main findings are that the beneficiaries of ISDS, in the aggregate, have overwhelmingly been companies with more than USD1 billion in annual revenue - especially extra-large companies with more than USD10 billion - and individuals with more than USD100 million in net wealth. ISDS has produced monetary benefits primarily for those companies or individuals at the expense of respondent states. Incidentally, we also found that extra-large companies' success rates in ISDS, especially at the merits stage, exceeded by a large margin the success rates of other claimants. It was evident that ISDS has also delivered substantial monetary benefits for the ISDS legal industry.
\end{abstract}

\section{Keywords:}

Investor-state arbitration, ISDS, compensation, wealth, corporations

\section{Author(s):}

Gus Van Harten

Osgoode Hall Law School

E: gvanharten@osgoode.yorku.ca
Pavel Malysheuski

Lockyer + Hein LLP

E: pavel.malysheuski@gmail.com 


\title{
Who has benefited financially from investment treaty arbitration? An evaluation of the size and wealth of claimants
}

\author{
Gus Van Harten and Pavel Malysheuski \\ Osgoode Hall Law School
}

\section{Introduction}

The sociological legitimacy of investment treaty arbitration, commonly known as investor-state dispute settlement (ISDS), appears to depend in part on an expectation that it benefits smaller businesses, not just large multinationals and the super wealthy. ${ }^{1}$ Proposed trade agreements that would expand greatly the role of ISDS - such as the U.S.-led Trans-Pacific Partnership (TPP), Europe-U.S. Transatlantic Trade and Investment Partnership (TTIP), and Canada-EU Comprehensive Economic and Trade Agreement (CETA) - have been promoted as delivering benefits for smaller enterprises. ${ }^{2}$

We examined the relationship between ISDS and smaller firms by collecting data on size and wealth of the foreign investors that have brought claims and received monetary awards due to ISDS. Our main findings are that the beneficiaries of ISDS-ordered financial transfers, ${ }^{3}$ in the aggregate, have overwhelmingly been companies with more than USD1 billion in annual revenue - especially extra-large companies with more than USD10 billion - and individuals who have over USD100 million in net wealth. ISDS has produced monetary benefits primarily for those companies or individuals at the expense of respondent states.

Thus, we found that companies with over USD1 billion in annual revenue and individuals with over USD100 million in net wealth received about $94.5 \%$ of the aggregate compensation (93.5\% if pre-award interest is included) ordered by first-instance ISDS tribunals. The remaining roughly $5.5 \%$ (or $6.5 \%$ ) of the ordered compensation went to companies with less than USD1 billion in annual revenues, unknown companies, and

\footnotetext{
${ }^{1}$ Our use of the term sociological legitimacy draws on D. Behn, O.K. Fauchald, and M. Langford, "How to approach 'legitimacy' for the book project Empirical Perspectives on the Legitimacy of International Investment Tribunals", prepared for the August 2015 workshop of the University of Oslo's Pluricourts Project. The comments from participants in the workshop are gratefully acknowledged.

${ }^{2}$ S. Lynch, "EU-US trade deal will benefit SMEs, says Brussels" The Irish Times (21 April 2015); P. Parks, "Critics of Trans-Pacific Partnership trade deal warn about arbitration clause". See also Movement for Responsibility in Trade Agreements, "Five questions SME businesses need to ask themselves about TTIP" https://moreforsmesthanttip.files.wordpress.com/2015/02/fivequestionssmesneedtoaskthemselvesaboutttipfinal-23-22.pdf

${ }^{3}$ We do not use the term "financial transfers" to describe ISDS orders of compensation to foreign investors in a negative way, as one participant in the Pluricourts Project workshop commented. Rather, we use the term in an effort to avoid conveying a negative or positive assessment of the legitimacy of such orders of compensation.
} 
individuals whose net wealth appeared to be less than USD100 million. It was evident that ISDS has also delivered substantial monetary benefits for the ISDS legal industry.

Incidentally, we also found that extra-large companies' success rates in ISDS (70.8\%), measured by simple win-loss outcomes at the jurisdictional and merits stages of an ISDS claim combined, exceeded by a large margin the success rates of other claimants $(42.2 \%)$. Yet the success rates of large (as opposed to extra-large) companies (44.7\%) and of super wealthy individuals (36.4\%) at both of these stages combined was comparable to those of other claimants (not including large or extra-large companies or super wealthy individuals) (42.5\%). The success rate of extra-large companies at the merits stage in particular (82.9\%) stood out compared to that of all other claimants (57.9\%).

Our analysis is descriptive in that it does not seek to predict future outcomes and does not use more complex statistical tools. One should approach all of the numbers presented here as approximate and keep in mind that variations in the experiences of different actors may be coincidental. We suggest that the most useful findings are those indicating a wide variation in these experiences and those appearing to contradict less evidence-based claims in the field.

\section{Findings}

\section{A. Ordered financial transfers by size or wealth of beneficiary}

It emerged from the analysis that ISDS - approached as a process that generates ordered financial transfers - has primarily benefited extra-large or large companies and super wealthy individuals. The great majority of ordered transfers, in the aggregate, have gone to such actors. Findings and data are outlined in the tables below. A more detailed breakdown of the dataset is appended to this paper.

1. Aggregate ordered compensation

\begin{tabular}{|c|c|c|c|c|c|c|}
\hline $\begin{array}{l}\text { Size or wealth } \\
\text { of beneficiary }\end{array}$ & $\begin{array}{l}\text { Measure of size or } \\
\text { wealth }\end{array}$ & $\begin{array}{l}\text { No. of cases } \\
\text { where } \\
\text { damages } \\
\text { ordered }\end{array}$ & $\begin{array}{l}\text { Total awarded, } \\
\text { raw sum }\end{array}$ & $\begin{array}{l}\text { \% awarded, } \\
\text { raw sum }\end{array}$ & $\begin{array}{l}\text { Total awarded, } \\
\text { raw sum + pre- } \\
\text { award interest }\end{array}$ & $\begin{array}{l}\text { \% awarded, } \\
\text { raw sum }+ \\
\text { pre-award } \\
\text { interest }\end{array}$ \\
\hline $\begin{array}{l}\text { Extra-large } \\
\text { company }\end{array}$ & $\begin{array}{l}>\$ 10 \text { billion in } \\
\text { annual revenue }\end{array}$ & 26 & 5282 million & $73.5 \%$ & 6718 million & $73.3 \%$ \\
\hline Large company & $\begin{array}{l}>\$ 1 \text { billion and }<\$ 10 \\
\text { billion in annual } \\
\text { revenue }\end{array}$ & 14 & 601 million & $8.4 \%$ & 780 million & $8.5 \%$ \\
\hline $\begin{array}{l}\text { Medium } \\
\text { company }\end{array}$ & $\begin{array}{l}>\$ 100 \text { million and } \\
<\$ 1 \text { billion in annual } \\
\text { revenue }\end{array}$ & 4 & 13 million & $0.2 \%$ & 17 million & $0.2 \%$ \\
\hline Small company & $<\$ 100$ million in & 4 & 80 million & $1.1 \%$ & 99 million & $1.1 \%$ \\
\hline
\end{tabular}




\begin{tabular}{|c|c|c|c|c|c|c|}
\hline & annual revenue & & & & & \\
\hline $\begin{array}{l}\text { Unknown } \\
\text { company }\end{array}$ & $\begin{array}{l}\text { Data unavailable } \\
\text { (DU) for annual } \\
\text { revenue }\end{array}$ & 13 & 132 million & $1.8 \%$ & 154 million & $1.7 \%$ \\
\hline $\begin{array}{l}\text { Super wealthy } \\
\text { individual }\end{array}$ & $\begin{array}{l}>\$ 100 \text { million in net } \\
\text { wealth }\end{array}$ & 5 & 905 million & $12.6 \%$ & 1072 million & $11.7 \%$ \\
\hline $\begin{array}{l}\text { Other } \\
\text { individual }\end{array}$ & $\begin{array}{l}<\$ 100 \text { million in net } \\
\text { wealth }\end{array}$ & 20 & 179 million & $2.5 \%$ & 325 million & $3.5 \%$ \\
\hline
\end{tabular}

\section{Breakdown of cases}

\begin{tabular}{|c|c|c|c|c|c|}
\hline Case & $\begin{array}{r}\text { Claimant } \\
\text { nationality } \\
\text { (with apparent } \\
\text { forum shopping } \\
\text { (FS) indicated) }\end{array}$ & $\begin{array}{r}\text { Corporation } \\
\text { or natural } \\
\text { person }\end{array}$ & $\begin{array}{r}\text { Claimant size or } \\
\text { wealth }\end{array}$ & $\begin{array}{l}\text { Amount } \\
\text { awarded }\end{array}$ & $\begin{array}{r}\text { Amount } \\
\text { awarded + pre- } \\
\text { award interest }\end{array}$ \\
\hline Occidental v Ecuador No 2 & USA & $\mathrm{C}$ & Extra-large & 1770 million & 2358 million \\
\hline Mobil v Venezuela & $\begin{array}{r}\text { Netherlands } \\
\text { (FS: USA) }\end{array}$ & C & Extra-large & 1600 million & 2067 million \\
\hline EDF v Argentina & Belgium, France & $\mathrm{C}$ & Extra-large & 136 million & 205 million \\
\hline BG Group v Argentina & UK & $\mathrm{C}$ & Extra-large & 185 million & 219 million \\
\hline CMS v Argentina & USA & C & Large & 133 million & 151 million \\
\hline CGE/ Vivendi v Argentina No 2 & France & C & Extra-large & 105 million & 169 million \\
\hline Siemens v Argentina & Germany & $\mathrm{C}$ & Extra-large & 238 million & 278 million \\
\hline Enron v Argentina & USA & $\mathrm{C}$ & Extra-large & 106 million & 142 million \\
\hline Azurix v Argentina & USA & $\mathrm{C}$ & Extra-large & 165 million & 186 million \\
\hline Sempra v Argentina & USA & $\mathrm{C}$ & Large & 128 million & 171 million \\
\hline Suez \& Interaguas & France & $\mathrm{C}$ & Extra-large & 405 million & 405 million \\
\hline CME v Czech Republic & $\begin{array}{r}\text { Netherlands } \\
\text { (FS: USA) }\end{array}$ & $\mathrm{N}$ & $\begin{array}{r}\text { Super wealthy } \\
\text { individual }\end{array}$ & 270 million & 395 million \\
\hline Stati v Kazakhstan & Moldova & $\mathrm{N}$ & $\begin{array}{r}\text { Super wealthy } \\
\text { individual }\end{array}$ & 498 million & 498 million \\
\hline Rumeli v Kazakhstan & $\begin{array}{r}\text { Turkey (FS: UK } \\
\text { for one of two } \\
\text { claimants, split } \\
\text { between two } \\
\text { nationalities i.e. } \\
\text { Turkey, UK) }\end{array}$ & $\mathrm{C}$ & $\begin{array}{r}\text { Large (with } \\
\text { Extra-large, } \\
\text { count as Extra- } \\
\text { large) }\end{array}$ & 125 million & 165 million \\
\hline Micula v Romania & Sweden & $\mathrm{N}$ & $\begin{array}{r}\text { Super wealthy } \\
\text { individual }\end{array}$ & 117 million & 156 million \\
\hline LG\&E v Argentina & USA & $\mathrm{C}$ & Extra-large & 57 million & 57 million \\
\hline Chevron v Ecuador No 1 & USA & $\mathrm{C}$ & Extra-large & 78 million & 96 million \\
\hline Siag v Egypt & $\begin{array}{r}\text { Italy (FS: dual } \\
\text { national of } \\
\text { Egypt) }\end{array}$ & $\mathrm{N}$ & Other individual & 75 million & 129 million \\
\hline ADC v Hungary & $\begin{array}{r}\text { Cyprus (FS: data } \\
\text { unavailable } \\
(\mathrm{DU}))\end{array}$ & C & Unknown & 76 million & 76 million \\
\hline Cargill v Mexico & USA & $\mathrm{C}$ & Extra-large & 77 million & 86 million \\
\hline Deutsche Bank v Sri Lanka & Germany & $\mathrm{C}$ & Extra-large & 60 million & 70 million \\
\hline Impregilo v Argentina & Italy & $\mathrm{C}$ & Large & 21 million & 28 million \\
\hline El Paso v Argentina & USA & $\mathrm{C}$ & Extra-large & 43 million & 66 million \\
\hline National Grid v Argentina & UK & $\mathrm{C}$ & Extra-large & 39 million & 54 million \\
\hline SAUR International v Argentina & France & $\mathrm{C}$ & Large & 40 million & 60 million \\
\hline Guaracachi v Bolivia & UK, USA & $\mathrm{C}$ & Small & 29 million & 36 million \\
\hline Pey Casado v Chile & Spain & $\mathrm{N}$ & $\begin{array}{l}\text { Other individual } \\
\text { (and non-profit }\end{array}$ & 10 million & 14 million \\
\hline
\end{tabular}




\begin{tabular}{|c|c|c|c|c|c|}
\hline & & & org) & & \\
\hline Eastern Sugar v Costa Rica & $\begin{array}{r}\text { Netherlands } \\
\text { (FS: UK and } \\
\text { Germany) }\end{array}$ & $\mathrm{C}$ & Extra-large & 35 million & 35 million \\
\hline $\begin{array}{l}\text { Occidental Petroleum v } \\
\text { Ecuador No } 1\end{array}$ & USA & $\mathrm{C}$ & Extra-large & 72 million & 75 million \\
\hline OKO Pankki Oyj v Estonia & Finland & $\mathrm{C}$ & Extra-large & 11 million & 14 million \\
\hline Kardassapoulos v Georgia & Greece & $\mathrm{N}$ & Other individual & 15 million & 45 million \\
\hline Fuchs v Georgia & Israel & $\mathrm{N}$ & Other individual & 15 million & 45 million \\
\hline RDC v Guatemala & USA & $\mathrm{N}$ & $\begin{array}{r}\text { Super wealthy } \\
\text { individual } \\
\end{array}$ & 11 million & 11 million \\
\hline TECO v Guatemala & USA & $\mathrm{C}$ & Large & 21 million & 23 million \\
\hline Abengoa v Mexico & Spain & $\mathrm{C}$ & Extra-large & 40 million & 42 million \\
\hline ADM v Mexico & USA & $\mathrm{C}$ & Large & 34 million & 37 million \\
\hline Metalclad v Mexico & USA (FS: DU) & C & Unknown & 17 million & 17 million \\
\hline SGS v Paraguay & Switzerland & $\mathrm{C}$ & Large & 39 million & 64 million \\
\hline Achmea v Slovakia No 1 & Netherlands & $\mathrm{C}$ & Extra-large & $\begin{array}{r}29 \text { million (net } \\
\text { any taxes) } \\
\end{array}$ & $\begin{array}{r}29 \text { million (net } \\
\text { any taxes) }\end{array}$ \\
\hline Walter Bau v Thailand & Germany & $\mathrm{C}$ & Small & 41 million & 50 million \\
\hline Tidewater v Venezuela & $\begin{array}{r}\text { Barbados (FS: } \\
\text { USA) } \\
\end{array}$ & $\mathrm{C}$ & Large & 46 million & 60 million \\
\hline Desert Line Products v Yemen & Oman & $\mathrm{N}$ & Other individual & 25 million & 30 million \\
\hline Funnekotter v Zim & Netherlands & $\mathrm{N}$ & Other individual & 11 million & 25 million \\
\hline $\begin{array}{l}\text { Continental Casualty v } \\
\text { Argentina }\end{array}$ & USA & $\mathrm{C}$ & Extra-large & 2.8 million & 3.6 million \\
\hline Saipem v Bangladesh & Italy & $\mathrm{C}$ & Extra-large & 6.3 million & 11 million \\
\hline Goetz v Burundi No 1 & Belgium & $\mathrm{N}$ & Other individual & 3 million & 3 million \\
\hline Goetz v Burundi No 2 & Belgium & $\mathrm{N}$ & Other individual & 1.2 million & 2.2 million \\
\hline SD Myers v Canada & USA & $\mathrm{C}$ & Medium & 6 million & 8.3 million \\
\hline MTD Equity v Chile & Malaysia & $\mathrm{C}$ & Medium & 5.9 million & 7.4 million \\
\hline $\begin{array}{l}\text { American Manufacturing } v \\
\text { Congo }\end{array}$ & USA (FS: DU) & $\mathrm{C}$ & Unknown & 9 million & 9 million \\
\hline Reinhard Unglaube v Costa Rica & Germany & $\mathrm{N}$ & Other individual & 3.1 million & 4.1 million \\
\hline Duke Energy v Ecuador & USA & C & Extra-large & 5.6 million & 28 million \\
\hline Middle East Cement v Egypt & Greece (FS: DU) & $\mathrm{C}$ & Unknown & 2.2 million & 3.8 million \\
\hline Wena Hotels v Egypt & UK (FS: DU) & $\mathrm{C}$ & Unknown & 8.8 million & 19 million \\
\hline White Industries v India & $\begin{array}{r}\text { Australia (FS: } \\
\text { DU) } \\
\end{array}$ & $\mathrm{C}$ & Unknown & 4.1 million & 11 million \\
\hline AIG Capital v Kazakhstan & USA & $\mathrm{C}$ & Extra-large & 6 million & 9.3 million \\
\hline Petrobart v Kyrgyzstan No 2 & $\begin{array}{r}\text { Gibraltar (FS: } \\
\text { DU) } \\
\end{array}$ & $\mathrm{C}$ & Unknown & 1.1 million & 1.5 million \\
\hline $\begin{array}{l}\text { Sistem Muhendislik v } \\
\text { Kyrgyzstan }\end{array}$ & Turkey (FS: DU) & C & Unknown & 8.5 million & 10 million \\
\hline Nykomb v Latvia & Sweden & $\mathrm{C}$ & Large & 3 million & 3.2 million \\
\hline Swembalt v Latvia & $\begin{array}{r}\text { Sweden (FS: } \\
\text { DU) }\end{array}$ & $\mathrm{C}$ & Unknown & 2.5 million & 2.8 million \\
\hline Feldman v Mexico & USA & $\mathrm{N}$ & Other individual & 1.7 million & 1.7 million \\
\hline Gemplus v Mexico & France & $\mathrm{C}$ & Extra-large & 4.5 million & 6.4 million \\
\hline Tecmed v Mexico & Spain & C & Extra-large & 5.5 million & 7.4 million \\
\hline Talsud v Mexico & Argentina & $\mathrm{C}$ & Small & 6 million & 9 million \\
\hline Arif v Moldova & France & $\mathrm{N}$ & Other individual & 2.8 million & 2.8 million \\
\hline Saar Papier v Poland & $\begin{array}{r}\text { Germany (FS: } \\
\text { DU) } \\
\end{array}$ & $\mathrm{C}$ & Unknown & 1.6 million & 2.2 million \\
\hline Awdi v Romania & USA & $\mathrm{N}$ & $\begin{array}{r}\text { Super wealthy } \\
\text { individual }\end{array}$ & 8.6 million & 12 million \\
\hline Renta 4 v Russia & Spain & $\mathrm{C}$ & Large & 2 million & 2.8 million \\
\hline RosInvestCo v Russia & UK (FS: DU) & $\mathrm{C}$ & Small & 3.5 million & 3.9 million \\
\hline Sedelmayer v Russia & Germany & $\mathrm{N}$ & Other individual & 2.4 million & 2.8 million \\
\hline PSEG v Turkey & USA & $\mathrm{C}$ & Large & 9 million & 15 million \\
\hline Alpha Projektholding v Ukraine & Austria & $\mathrm{N}$ & Other individual & 3 million & 8 million \\
\hline Lemire $v$ Ukraine No 2 & USA & $\mathrm{N}$ & Other individual & 8.7 million & 8.7 million \\
\hline
\end{tabular}




\begin{tabular}{|c|c|c|c|c|c|}
\hline Pope \& Talbot v Canada & USA & $\mathrm{C}$ & Medium & 460000 & 460000 \\
\hline Mitchell v Congo & USA & $\mathrm{N}$ & Other individual & 750000 & 1.1 million \\
\hline Swisslion v Macedonia & $\begin{array}{r}\text { Switzerland (FS: } \\
\text { Serbia) }\end{array}$ & $\mathrm{C}$ & Medium & 440000 & 490000 \\
\hline Bogdanov v Moldova No 1 & Russia & $\mathrm{N}$ & Other individual & 280000 & 280000 \\
\hline Bogdanov v Moldova No 2 & Russia & $\mathrm{N}$ & Other individual & 160000 & $\begin{array}{r}\text { data unavailable } \\
\text { (DU) }\end{array}$ \\
\hline Tza Yap Shum v Peru & China & $\mathrm{N}$ & Other individual & 790000 & 1 million \\
\hline Maffezini v Spain & Argentina & $\mathrm{N}$ & Other individual & 410000 & 490000 \\
\hline AAPL v Sri Lanka & UK (FS DU) & C & Unknown & 460000 & 610000 \\
\hline Fedax v Venezuela & $\begin{array}{r}\text { Netherlands (FS } \\
\text { DU) }\end{array}$ & $\mathrm{C}$ & Unknown & 600000 & 760000 \\
\hline Nordzucker v Poland & Germany & $\mathrm{C}$ & Large & 0 & 0 \\
\hline Rompetrol v Romania & $\begin{array}{r}\text { Netherlands } \\
\text { (FS: Romania) }\end{array}$ & C & Large & 0 & 0 \\
\hline Al-Bahloul v Tajikistan & Austria & $\mathrm{N}$ & Other individual & 0 & 0 \\
\hline Biwater v Tanzania & UK & $C$ & Unknown & 0 & 0 \\
\hline Total: 86 cases & & $\begin{array}{l}\text { C: } 61 \\
N: 25\end{array}$ & $\begin{array}{r}\text { X-large: } 26 \\
\text { Large: } 14 \\
\text { Medium: } 4 \\
\text { Small: } 4 \\
\text { Unknown: } 13 \\
\text { Super wealthy } \\
\text { individual: } 5 \\
\text { Other } \\
\text { individual: } 20\end{array}$ & $\begin{array}{r}\text { Total: } 7191 \\
\text { million }\end{array}$ & $\begin{array}{r}\text { Total: } 9164 \\
\text { million }\end{array}$ \\
\hline
\end{tabular}

\section{The Yukos cases}

As noted in the appendix, three Yukos cases that led to a combined award of USD50 billion are reported separately from the above data due to the sheer size of the overall order of compensation and to assist the reader in drawing his or her own conclusions. For our part, we classified these cases - arising claims by the companies Yukos Universal Limited (YUL), Hulley Enterprises Limited (Hulley), and Veteran Petroleum Trust - as cases brought by a super wealthy individual, Mikhail Khodorkovsky, on the following basis. $^{4}$

In 1997, several Russian businessmen including Mr. Khodorkovsky registered an offshore company in Gibraltar called Flaymon Limited, which was soon after re-named Group MENATEP Limited (MENATEP). When the relevant ISDS claims were filed, the share capital of MENATEP was distributed among Khodorkovsky (9.5\%), Leonid Nevzlin (8\%), Mikhail Brudno (7\%), Platon Lebedev (7\%), Vladimir Dubov (7\%), Vasily Shakhnovsky (7\%), and others (4.5\%). The remaining $50 \%$ was held by a trust fund called

\footnotetext{
${ }^{4}$ The detailed research on these cases case was conducted by Malysheuski based on online sources: http://www.pca-cpa.org/VET-_Interim_Award_-_30_Nov_200972dc.PDF?fil_id=2721; https://en.wikipedia.org/wiki/Bank_Menatep\#Group_Menatep_Limited; https://en.wikipedia.org/wiki/Millhouse_Capital; https://ru.wikipedia.org/wiki/Group_MENATEP; http://khodorkovsky.ru/media/0001-293_\%5Bt.175_I.d._1-293\%5D.doc
} 
the Special Trust Arrangement, the sole beneficiary of which was Khodorkovsky. In effect, Khodorkovsky directly and indirectly owned $59.5 \%$ of MENATEP. MENATEP owned in turn $100 \%$ of the shares of YUL, another off-shore company registered in the Isle of Man. YUL in turn owned $100 \%$ of the shares of Hulley, an off-shore company registered in Cyprus that owned $57.47 \%$ of the shares of Joint Stock Company "NC" Yukos (another 3.54\% of this company was owned by YUL directly). YUL also had another 100\%-owned Cyprus-registered subsidiary, Veteran Petroleum Ltd (VPL). At the time of the Yukos bankruptcy in 2005, MENATEP controlled 51\% of Yukos shares through YUL and Hulley and an additional 10\% through Veteran Petroleum Trust (a trust established by VPL under the laws of the state of Jersey). ${ }^{5}$ Effectively, a group of six Russian oligarchs including Khodorkovsky controlled $62 \%$ of Yukos through the off-shore vehicles YUL, Hulley, and VPL at the material times. ${ }^{6}$ By his ownership of the largest stake, we considered Khodorkovsky, in objective terms, to be the directing or influencing mind in the Yukos group of entities.

Incidentally, these cases appear to be examples of forum-shopping whereby individuals were allowed to bring ISDS claims against their own state by using companies or other entities abroad. Khodorkovsky, Lebedev, and Shakhnovsky are Russian citizens; Brudno, Nevzlin, and Dubov acquired Israeli citizenship in addition to their Russian citizenship after leaving Russia for Israel in 2003, after criminal proceedings were brought against them in Russia.

In any event, due to their size, the three Yukos awards were distinct from the others in the dataset and so have been reported separately. The exclusion of these cases reduced vastly - from $89 \%$ to $12.6 \%$ (or from $86.3 \%$ to $11.7 \%$ including pre-award interest) - the proportion of the total compensation that was ordered for super wealthy individuals.

\begin{tabular}{|c|c|c|c|c|c|}
\hline Case & $\begin{array}{r}\text { Claimant } \\
\text { nationality (with } \\
\text { apparent forum } \\
\text { shopping (FS) } \\
\text { indicated) }\end{array}$ & $\begin{array}{r}\text { Corporation } \\
\text { or natural } \\
\text { person }\end{array}$ & $\begin{array}{r}\text { Claimant } \\
\text { size or } \\
\text { wealth }\end{array}$ & Amount awarded & $\begin{array}{l}\text { Amount awarded }+ \\
\text { pre-award interest }\end{array}$ \\
\hline Hulley v Russia & Cyprus (FS: Russia) & $\mathrm{N}$ & $\begin{array}{r}\text { Super } \\
\text { wealthy } \\
\text { individual }\end{array}$ & 39972 million & 39972 million \\
\hline
\end{tabular}

\footnotetext{
${ }^{5}$ In the case of VPL, a Swiss court found that Khodorkovsky, Lebedev, Golubovitch, Nevzlin, Doubov, Brudno and Chakhnovski were the beneficial owners of the totality of Yukos shares allegedly owned or controlled by VPL; Veteran Petroleum Limited (Cyprus) v. Russian Federation, PCA Case No. AA 228 (Interim Award on Jurisdiction and Admissibility, 30 November 2009), para. 71 (E-43) and 420.

${ }^{6}$ Another $8.8 \%$ of Yukos was controlled by Roman Abramovich, another Russian oligarch, through his United Kingdom vehicle Millhouse Capital. The remaining approximately $39 \%$ of Yukos stock was held by various hedge funds, American Depository Receipts (ADRs), and minor shareholders.
} 


\begin{tabular}{|l|r|r|r|r|r|}
\hline $\begin{array}{l}\text { Veteran Petroleum v } \\
\text { Russia }\end{array}$ & Cyprus (FS: Russia) & $\mathrm{N}$ & $\begin{array}{r}\text { Super } \\
\text { wealthy } \\
\text { individual }\end{array}$ & 8203 million & 8203 million \\
\hline Yukos v Russia & $\begin{array}{r}\text { Isle of Man (FS: } \\
\text { Russia) }\end{array}$ & $\mathrm{N}$ & $\begin{array}{r}\text { Super } \\
\text { wealthy } \\
\text { individual }\end{array}$ & 1846 million & 1846 million \\
\hline
\end{tabular}

\section{Apparent forum-shopping}

The investigation of ultimate ownership of ISDS claimants brought to light some cases of apparent forum-shopping. The concept of forum-shopping here included situations where the historical base or nationality of the ultimate owner in a claimant group differed from that of the opposite state under the relevant treaty used for the ISDS claim.

The primary finding was that this forum-shopping had a major effect for U.S. beneficiaries; the ordered compensation increased by $70 \%$ after accounting for the forum-shopping. It also had a major effect for Netherlands' beneficiaries, leading to a decrease of $98 \%$. In turn, the ordered compensation for U.S. beneficiaries rose from a minority (39\%) to a majority (66\%) of the overall total. Accounting for this forumshopping also modestly increased the ordered compensation for UK, German, or (in a case with very little awarded) Serbian beneficiaries and modestly decreased it for Turkish or, for the tiny award to a Serbian beneficiary, Swiss beneficiaries.

The following table indicates the ordered transfers by country, with and without apparent forum-shopping. It also includes notes on our incidental findings on forumshopping including a note of those situations where there was apparent forum-shopping but data was unavailable on ultimate ownership of the ISDS claim.

\begin{tabular}{|c|c|c|c|c|c|c|}
\hline $\begin{array}{l}\text { Country of } \\
\text { ISDS claim }\end{array}$ & No. of cases & $\begin{array}{r}\text { No. of cases } \\
\text { accounting for } \\
\text { apparent } \\
\text { forum- } \\
\text { shopping }\end{array}$ & $\begin{array}{l}\text { Amount } \\
\text { awarded }\end{array}$ & $\begin{array}{r}\text { Amount } \\
\text { awarded } \\
\text { accounting for } \\
\text { apparent FS }\end{array}$ & $\begin{array}{l}\text { Amount including } \\
\text { pre-award interest }\end{array}$ & $\begin{array}{l}\text { Amount including } \\
\text { pre-award } \\
\text { interest } \\
\text { accounting for } \\
\text { apparent FS }\end{array}$ \\
\hline USA & $\begin{array}{r}25.5 \\
\text { (one shared } \\
\text { with UK) }\end{array}$ & 28.5 & 2785 million & 4701 million & 3591 million & 6113 million \\
\hline Netherlands & 7 & $\begin{array}{r}2 \\
\text { (includes one } \\
\text { FS: data } \\
\text { unavailable } \\
(D U))\end{array}$ & 1946 million & 40 million & 2551 million & 54 million \\
\hline Germany & 7 & $\begin{array}{r}7.5 \\
\text { (includes one } \\
\text { FS: DU) }\end{array}$ & 346 million & 363.5 million & 407 million & 424.5 million \\
\hline UK & $\begin{array}{r}6.5 \\
\text { (one shared } \\
\text { with USA) }\end{array}$ & $\begin{array}{r}7.5 \text { cases } \\
\text { (two FS cases } \\
\text { shared with }\end{array}$ & 251 million & 331 million & 314 million & 414 million \\
\hline
\end{tabular}




\begin{tabular}{|c|c|c|c|c|c|c|}
\hline & & $\begin{array}{r}\text { Germany and } \\
\text { Turkey) } \\
\text { (includes } 2 \text { FS: } \\
\text { DU) }\end{array}$ & & & & \\
\hline France & $\begin{array}{r}5.5 \\
\text { (one shared } \\
\text { with Belgium) }\end{array}$ & 5.5 & 625 million & NA & 746 million & NA \\
\hline Spain & 4 & 4 & 58 million & NA & 66 million & $\mathrm{NA}$ \\
\hline Italy & 3 & $\begin{array}{r}3 \\
\text { (includes major } \\
\text { award where } \\
\text { claimant was } \\
\text { dual national, } \\
\text { not classified as } \\
\text { FS) }\end{array}$ & 102 million & NA & 168 million & NA \\
\hline Sweden & 3 & $\begin{array}{r}3 \\
\text { (includes one } \\
\text { FS: DU) } \\
\end{array}$ & 122 million & NA & 162 million & NA \\
\hline Belgium & $\begin{array}{r}2.5 \\
\text { (one shared } \\
\text { with France) } \\
\end{array}$ & 2.5 & 72 million & NA & 108 million & NA \\
\hline Argentina & 2 & 2 & 7 million & NA & 10 million & NA \\
\hline Austria & 2 & 2 & 3 million & NA & 8 million & NA \\
\hline Greece & 2 & $\begin{array}{r}2 \\
\text { (includes one } \\
\text { FS: DU) } \\
\end{array}$ & 17 million & NA & 49 million & $\mathrm{NA}$ \\
\hline Switzerland & 2 & 1 & 39 million & 39 million & 65 million & 64 million \\
\hline Turkey & 2 & $\begin{array}{r}1.5 \\
\text { (one shared } \\
\text { with UK) } \\
\end{array}$ & 134 million & 71 million & 175 million & 92.5 million \\
\hline Australia & 1 & $\begin{array}{r}1 \\
\text { (includes } 1 \mathrm{FS}: \\
\mathrm{DU})\end{array}$ & 4.1 million & NA & 11 million & NA \\
\hline Barbados & 1 & 0 & 46 million & 0 & 60 million & 0 \\
\hline China & 1 & 1 & 0.8 million & NA & 1 million & NA \\
\hline Cyprus & 1 & $\begin{array}{r}1 \\
\text { (includes } 1 \mathrm{FS}: \\
\mathrm{DU})\end{array}$ & 76 million & NA & 76 million & $\overline{N A}$ \\
\hline Finland & 1 & 1 & 11 million & NA & 14 million & NA \\
\hline Gibraltar & 1 & $\begin{array}{r}1 \\
\text { (includes } 1 \mathrm{FS}: \\
\mathrm{DU})\end{array}$ & 1.1 million & NA & 1.5 million & NA \\
\hline Israel & 1 & 1 & 15 million & NA & 45 million & NA \\
\hline Malaysia & 1 & 1 & 6 million & NA & 7 million & NA \\
\hline Moldova & 1 & 1 & 498 million & NA & 498 million & NA \\
\hline Oman & 1 & 1 & 25 million & NA & 35 million & NA \\
\hline Russia & 2 & 2 & 0.4 million & NA & 0.4 million & NA \\
\hline Romania & 0 & 1 & NA & 0 & NA & 0 \\
\hline Serbia & 0 & 1 & NA & 0.4 million & NA & 0.5 million \\
\hline
\end{tabular}

\section{B. Legal outcomes by size or wealth of ISDS beneficiary}


We also compared legal outcomes in ISDS cases, at the jurisdictional, merits, and combined stages of a case, to the size or wealth of claimants. The findings are outlined below.

Keeping in mind that these are descriptive statistics, the only noteworthy findings appears to be the higher success rate of extra-large companies: $70.8 \%$ combined over 48 cases with a confirmed adjudicative resolution at the jurisdictional and/ or the merits stage. In contrast, the success rate of other claimants was $42.2 \%$ combined over 166 cases. However, the success rates of large (as opposed to extra-large) companies (44.7\% over 38 cases) and of super wealthy individuals (36.4\% over 22 cases) was comparable to those of other claimants not including large or extra-large companies or super wealthy individuals (42.5\% over 106 cases).

In particular, the success rate of extra-large companies at the merits stage $(82.9 \%$ over 41 cases) was much higher than that of other claimants (57.9\% over 121 cases).

\begin{tabular}{|c|c|c|c|c|c|c|c|c|c|}
\hline $\begin{array}{l}\text { Claimant } \\
\text { size or } \\
\text { wealth }\end{array}$ & $\begin{array}{l}\text { Cases } \\
\text { coded for } \\
\text { size or } \\
\text { wealth }\end{array}$ & $\begin{array}{l}\text { Cases with } \\
\text { confirmed } \\
\text { adjudicative } \\
\text { resolution }\end{array}$ & $\begin{array}{l}\text { Outcome: } \\
\text { jurisdiction } \\
\text { not found }\end{array}$ & $\begin{array}{l}\text { Outcome: } \\
\text { jurisdiction } \\
\text { found }\end{array}$ & $\begin{array}{l}\text { Success } \\
\text { rate: } \\
\text { jurisdiction }\end{array}$ & $\begin{array}{l}\text { Outcome: } \\
\text { violation } \\
\text { not found }\end{array}$ & $\begin{array}{l}\text { Outcome: } \\
\text { violation } \\
\text { found }\end{array}$ & $\begin{array}{l}\text { Success } \\
\text { rate: } \\
\text { merits }\end{array}$ & $\begin{array}{l}\text { Overall } \\
\text { success } \\
\text { rate }\end{array}$ \\
\hline $\begin{array}{l}\text { Extra- } \\
\text { large } \\
\text { company }\end{array}$ & 70 & 48 & 7 & 54 & $88.5 \%$ & 7 & 34 & $82.9 \%$ & $70.8 \%$ \\
\hline $\begin{array}{l}\text { Large } \\
\text { company }\end{array}$ & 54 & 38 & 9 & 39 & $81.3 \%$ & 12 & 17 & $58.6 \%$ & $44.7 \%$ \\
\hline $\begin{array}{l}\text { Medium } \\
\text { company }\end{array}$ & 18 & 9 & 1 & 16 & $94.1 \%$ & 3 & 5 & $62.5 \%$ & $55.6 \%$ \\
\hline $\begin{array}{l}\text { Small } \\
\text { company }\end{array}$ & 16 & 11 & 3 & 10 & $76.9 \%$ & 3 & 5 & $62.5 \%$ & $45.5 \%$ \\
\hline $\begin{array}{l}\text { Unknown } \\
\text { company }\end{array}$ & 48 & 41 & 11 & 31 & $73.8 \%$ & 16 & 14 & $46.7 \%$ & $34.1 \%$ \\
\hline $\begin{array}{l}\text { Super } \\
\text { wealthy } \\
\text { individual }\end{array}$ & 26 & 22 & 8 & 15 & $65.2 \%$ & 6 & 8 & $57.1 \%$ & $36.4 \%$ \\
\hline \multirow[t]{2}{*}{$\begin{array}{l}\text { Other } \\
\text { individual }\end{array}$} & 57 & 45 & 13 & 37 & $74.0 \%$ & 11 & 21 & $65.6 \%$ & $46.7 \%$ \\
\hline & 292 & 214 & 52 & 201 & $79.5 \%$ & 58 & 104 & $64.2 \%$ & $48.6 \%$ \\
\hline
\end{tabular}

C. Size or wealth of claimants and ordered financial transfers compared to ISDS costs

We also compared the data on ordered compensation, classified by claimant size or wealth, to approximate legal and arbitration costs in ISDS. The estimate of costs per case was taken from an OECD survey that reported an average of USD8 million in ISDS legal and arbitration costs per case for both sides, with some cases exceeding USD30 million in costs. ${ }^{7}$

\footnotetext{
${ }^{7}$ D. Gaukrodger and K. Gordon, "Investor-State Dispute Settlement: A Scoping Paper for the Investment Policy Community", OECD Working Paper on International Investment No. 2012/03 (OECD, 2012), 19. The OECD analysis
} 
These estimated costs are approximate because of a lack of detailed public information on costs in ISDS awards. Also, the use of averages may skew the numbers in individual cases if costs are higher in cases brought, for example, by larger or wealthier actors. As discussed in the appendix to this paper, tracking of ISDS costs and ordered compensation also does not cover all potential costs and benefits of ISDS.

The estimates do not account for cost shifting, which sometimes occurs in ISDS cases. However, on this point, in 196 cases with the relevant data, cost shifting appeared on average per case to have favoured respondent states for nearly all categories of claimant size/ wealth. The clear exception was extra-large companies, which paid one third of the costs on average per case where cost shifting occurred). ${ }^{8}$

Despite these limitations, the estimates are useful in evaluating tentatively whether the financial position of small or medium companies or non-super wealthy individuals appears to have been improved due to ISDS, not only compared to larger or wealthier investors, but also in absolute terms. That is, the estimate of average ISDS costs - taken here to be USD4 million per case for the claimant investor(s) - suggests that a large majority of these smaller investors (82\%) spent more on ISDS costs than they received in ordered transfers.

The approximate data on aggregate ordered compensation, accounting for assumed ISDS costs, is outlined below.

\begin{tabular}{|l|l|l|l|l|l|l|r|}
\hline $\begin{array}{l}\text { Claimant size } \\
\text { or wealth }\end{array}$ & $\begin{array}{l}\text { Measure of } \\
\text { size or } \\
\text { wealth }\end{array}$ & $\begin{array}{l}\text { Cases with } \\
\text { confirmed } \\
\text { adjudicative } \\
\text { resolution } \\
\text { received } \\
\text { damages }\end{array}$ & $\begin{array}{l}\text { Total } \\
\text { awarded, raw } \\
\text { sum only }\end{array}$ & $\begin{array}{l}\text { Total } \\
\text { awarded, } \\
\text { raw sum } \\
\text { plus pre- } \\
\text { award } \\
\text { interest }\end{array}$ & $\begin{array}{l}\text { Total } \\
\text { estimated } \\
\text { ISDS legal } \\
\text { and } \\
\text { arbitration } \\
\text { costs }\end{array}$ & $\begin{array}{l}\text { Net gain/ } \\
\text { loss }\end{array}$ & \\
\hline $\begin{array}{l}\text { Extra-large } \\
\text { company }\end{array}$ & $\begin{array}{l}>\$ 10 \\
\text { billion in } \\
\text { annual } \\
\text { revenue }\end{array}$ & 48 & 26 & 5282 million & 6718 million & 192 million & +6526 \\
million
\end{tabular}

covered 143 available ISDS awards of which 28 provided information on arbitral fees and legal expenses, 81 provided some information on costs, and 62 provided no such information.

${ }^{8}$ Of the 292 cases with information on claimant size, costs were found to have been shifted in 77 of 198 cases with available data, of which 25 cases were brought by a small or medium company or a non-super wealthy individual (with average cost shifting per case of $57.8 \%$ allocated to the claimant and $42.2 \%$ to the respondent) and 14 cases by an unknown company ( $57.6 \%$ to the claimant). These portions of shifted cost borne by claimants were modestly lower than in cases brought by large companies (67.8\% to the claimant in 14 cases) and tycoons (62.5\% to the claimant in 10 cases) and substantially higher than in cases brought by extra-large companies ( $33.4 \%$ to the claimant in 14 cases). 


\begin{tabular}{|c|c|c|c|c|c|c|c|}
\hline & revenue & & & & & & \\
\hline $\begin{array}{l}\text { Medium } \\
\text { company }\end{array}$ & $\begin{array}{l}>\$ 100 \\
\text { million and } \\
<\$ 1 \text { billion } \\
\text { in annual } \\
\text { revenue }\end{array}$ & 9 & 4 & 13 million & 17 million & 36 million & -19 million \\
\hline $\begin{array}{l}\text { Small } \\
\text { company }\end{array}$ & $\begin{array}{l}\$ 100 \\
\text { million in } \\
\text { annual } \\
\text { revenue }\end{array}$ & 11 & 4 & 80 million & 99 million & 44 million & +55 million \\
\hline $\begin{array}{l}\text { Unknown } \\
\text { company }\end{array}$ & $\begin{array}{l}\text { data } \\
\text { unavailable } \\
\text { (DU) for } \\
\text { annual } \\
\text { revenue } \\
\end{array}$ & 41 & 13 & 132 million & 154 million & 164 million & -10 million \\
\hline $\begin{array}{l}\text { Super wealthy } \\
\text { individual }\end{array}$ & $\begin{array}{l}>\$ 100 \\
\text { million in } \\
\text { net wealth }\end{array}$ & 22 & 5 & 905 million & 1072 million & 88 million & $\begin{array}{r}+984 \\
\text { million }\end{array}$ \\
\hline $\begin{array}{l}\text { Other } \\
\text { individual }\end{array}$ & $\begin{array}{l}<\$ 100 \\
\text { million in } \\
\text { net wealth }\end{array}$ & 45 & 20 & 179 million & 325 million & 180 million & $\begin{array}{r}+145 \\
\text { million }\end{array}$ \\
\hline
\end{tabular}

Within this grouping of smaller enterprises, the tentative analysis suggested that a net loss in ISDS cases for medium companies was outweighed by a net gain for small companies and non-super wealthy individuals. For companies with unknown annual revenues, it appeared that there was a net loss

The overall gain for smaller enterprises appeared to be concentrated in a fairly small minority of beneficiaries. At the case level, a net gain was apparent in 12 (18.5\%) of 65 cases with a confirmed adjudicative resolution and not involving an extra-large or large company, an unknown company, or a super wealthy individual. If one included unknown companies in the grouping, a net gain appeared in 18 (17\%) of 106 cases. These were the cases in which the smaller or unknown investor received an ordered transfer exceeding the assumed average of USD4 million in ISDS legal and arbitration costs. These 18 cases are listed below.

\begin{tabular}{|c|c|c|c|c|}
\hline Case & $\begin{array}{r}\text { Claimant } \\
\text { nationality (with } \\
\text { apparent forum } \\
\text { shopping } \\
\text { indicated) } \\
\end{array}$ & $\begin{array}{r}\text { Claimant size or } \\
\text { wealth }\end{array}$ & Amount awarded & $\begin{array}{c}\text { Amount plus pre- } \\
\text { award interest } \\
\text { where available }\end{array}$ \\
\hline Siag v Egypt & $\begin{array}{r}\text { Italy (FS: dual } \\
\text { national of Egypt) }\end{array}$ & Other individual & 75 million & 129 million \\
\hline ADC v Hungary & $\begin{array}{r}\text { Cyprus (FS: data } \\
\text { unavailable (DU)) }\end{array}$ & Unknown & 76 million & 76 million \\
\hline Guaracachi v Bolivia & UK, USA & Small & 29 million & 36 million \\
\hline Pey Casado v Chile & Spain & $\begin{array}{r}\text { Other individual } \\
\text { (and non-profit } \\
\text { org) }\end{array}$ & 10 million & 14 million \\
\hline Kardassapoulos v Georgia & Greece & Other individual & 15 million & 45 million \\
\hline Fuchs v Georgia & Israel & Other individual & 15 million & 45 million \\
\hline Metalclad v Mexico & USA (FS: DU) & Unknown & 17 million & 17 million \\
\hline Walter Bau v Thailand & Germany & Small & 41 million & 50 million \\
\hline $\begin{array}{l}\text { Desert Line Products v } \\
\text { Yemen }\end{array}$ & Oman & Other individual & 25 million & 30 million \\
\hline Funnekotter v Zim & Netherlands & Other individual & 11 million & 25 million \\
\hline
\end{tabular}




\begin{tabular}{|c|c|c|c|c|}
\hline $\begin{array}{l}\text { American Manufacturing } \\
\text { v Congo }\end{array}$ & USA (FS: DU) & Unknown & 9 million & 9 million \\
\hline $\begin{array}{l}\text { Reinhard Unglaube v } \\
\text { Costa Rica }\end{array}$ & Germany & Other individual & 3.1 million & 4.1 million \\
\hline Wena Hotels v Egypt & UK (FS: DU) & Unknown & 8.8 million & 19 million \\
\hline White Industries v India & Australia (FS: DU) & Unknown & 4.1 million & 11 million \\
\hline $\begin{array}{l}\text { Sistem Muhendislik v } \\
\text { Kyrgyzstan }\end{array}$ & Turkey (FS: DU) & Unknown & 8.5 million & 10 million \\
\hline Talsud v Mexico & Argentina & Small & 6 million & 9 million \\
\hline $\begin{array}{l}\text { Alpha Projektholding v } \\
\text { Ukraine }\end{array}$ & Austria & Other individual & 3 million & 8 million \\
\hline Lemire v Ukraine No 2 & USA & Other individual & 8.7 million & 8.7 million \\
\hline
\end{tabular}

Therefore, from this tentative and limited perspective, ISDS appears to have created among smaller and unknown investors a small number of lucky winners and a much larger number of apparent losers.

The data on ISDS costs also highlights financial benefits of ISDS for ISDS lawyers, arbitrators, experts, and other actors who earn income from ISDS fees. In 214 ISDS cases with a confirmed adjudicative resolution, based on the OECD estimate of ISDS costs the total payments of fees from disputing parties to the ISDS industry would have been about USD1.7 billion.

\section{Conclusion}

The purpose of this article was to assess claims about ISDS linked to the size and wealth of foreign investors who bring claims and obtain orders of compensation in their favour. Broadly, ISDS was approached as a system that generates financial transfers, with a focused on ordered compensation by first-instance tribunals. The findings on the apparent transfers can be summarized as follows (all figures in USD):

From states to extra-large ${ }^{9}$ companies:

From states to super wealthy individuals ${ }^{10}$ :

From states to large ${ }^{11}$ companies:

From states to other individuals ${ }^{12}$ :

From states to other ${ }^{13}$ companies:

Total from states to foreign investors:

From states to ISDS industry: ${ }^{14}$

From other companies to ISDS industry:
6718 million in 48 cases

1072 million in 22 cases

780 million in 38 cases

325 million in 45 cases

270 million in 61 cases

9164 million in 214 cases

856 million

244 million

\footnotetext{
${ }^{9}$ Over USD10 billion in annual revenue.

${ }^{10}$ Over USD100 million in net wealth.

${ }^{11}$ Over USD1 billion in annual revenue, less than USD10 billion.

12 Under USD100 million in net wealth. Includes both confirmed and apparent non-super wealthy individuals.

${ }^{13}$ Over USD100 million in annual revenue, less than USD1 billion. Includes companies for which annual revenues were unknown.

${ }^{14}$ Primarily lawyers and arbitrators but also including paid experts and arbitral institutions.
} 
From extra-large companies to ISDS industry: 192 million

From other individuals to ISDS industry: $\quad 180$ million

From large companies to ISDS industry: 152 million

From super wealthy individuals to ISDS industry: 88 million

Total from disputing parties to ISDS industry: 1700 million in 214 cases

From the same perspective, net winners and losers in the aggregate emerged as follows:

\section{Big winners}

Extra-large companies:

ISDS industry:

Super wealthy individuals:

Large companies:

\section{Modest winners}

Other individuals:

Small and medium companies:

\section{Modest losers}

Companies with unknown annual revenue: $\quad-10$ million ( -0.2 million)

\section{Big losers}

Respondent states:
6526 million (136 million per adjudicated case)

1712 million (8 million)

984 million (45 million)

628 million (17 million)

145 million (3 million)

36 million ( 2 million)

These data are not based on elaborate statistical analysis; they support descriptive findings about what has happened in ISDS but should not be taken as predictions of future outcomes. The findings may reflect coincidences and be subject to a risk of error that precludes predictive claims. The main contribution of our study is to show how ISDS has unfolded from the point of view of financial transfers based on a comprehensive review of known ISDS cases. The findings are perhaps most useful where they reveal wide variations in the experiences of different actors and where they cast doubt on claims about ISDS that are not based on comparable evidence. 
Appendix: Limitations, dataset, and methodology

Our research and analysis focused on aggregate ordered compensation by first-instance tribunals. We did not attempt to track actual records of payment of awards or account for changes in ordered compensation due to set aside or annulment decisions. Also, there are other ways to measure claimant success in ISDS. We have moved beyond an approach based on win-loss outcomes in ISDS litigation to a somewhat more complex measure based on aggregate ordered compensation. More ambitiously, one could assess claimant success in terms of less overt and non-financial costs and benefits, such as the utility of ISDS as a tool to influence regulatory-decision-making. Other forms of assessment would be more comprehensive but also less measurable numerically and more amenable, we suspect, to qualitative than quantitative tools. For these and other reasons discussed in the introduction to this paper and below, our research and analysis generates only an approximate and descriptive picture of aspects of ISDS as a system that leads to financial transfers.

The underlying dataset for this paper included all known and publicly-available ISDS cases that led to a decision on jurisdiction, at least, as of spring of 2015. The most relevant fields in the dataset for this paper were: claimant nationality, date and outcome of award on jurisdiction, date and outcome of award on merits, amount awarded (converted to USD as of the date of the award), and damages awarded with and without pre-award interest (calculated, where applicable, using the interest rate and date range stipulated by the tribunal). Awards were not adjusted for time value of money because our aim was to provide simple and descriptive findings supported by public data where none presently exists on the issue.

The underlying dataset was compiled by five law school students, most recently Ryan De Vries, working as research assistants over a period of seven years. Each assistant, after initial training, collected information on ISDS cases from publicly-available awards and other decisions up to the relevant time cut-off. The main source of awards and other decisions was italaw.com supplemented by official websites of the International Centre for Settlement of Investment Disputes (ICSID), the Permanent Court of Arbitration (PCA), the Stockholm Chamber of Commerce (SCC), and the federal governments of Canada, Mexico, and the United States. An award or decision had to be available on italaw.com and allow for verification as a treaty-based case, or the case had to be identified as treaty-based on one of the official websites just listed, in order for the case to be included in the analysis. Coding results were screened by the author (i.e. approximately half of the coding decisions were checked for errors) and past coding was checked and sometimes re-coded by another research assistant. For the data used in the present article, relevant coding rarely involved significant discretionary choices by 
the coder; rather, it focused on descriptive information on ISDS cases that tended to be clear in the award or other decision. Considering the extent of information collected and the absence of a comprehensive double or triple coding process, there is a risk of occasional error in data entry.

In a significant minority of cases in the dataset, roughly $15 \%$, one or more of the relevant awards or decisions were not public. Also, there are an unknown number of cases that can be assumed to be completely confidential. For the dataset overall, there is a reasonable prospect that this confidentiality may impact the findings, especially for fields connected to arbitration forums and where one forum is more open than another. For the present analysis, in one exceptional case (Suez \& Interaguas $v$ Argentina) public information was available up to, but not for, a known award on damages. For this case only, a non-official source (Investment Arbitration Reporter) was relied on to code the amount awarded to the claimant.

Within this ISDS case dataset, all confirmed treaty-based cases were then classified for size or wealth of the claimant up to the spring of 2014 (specifically, up to posting on italaw.com as of 18 April 2014). Co-author Pavel Malysheuski - a corporate/ commercial and securities lawyer with knowledge of ISDS - determined reasonable measures of the size and wealth of claimants and coded the cases for size and wealth of the claimant. Companies were classified based on their annual revenue as small (under USD100 million in annual revenue), medium (over USD100 million, under USD1 billion) large (over USD1 billion), or extra-large (over USD10 billion). For individuals, those with an apparent net wealth of more than USD100 million were classified as super wealthy; those whose net wealth was not found to exceed this threshold as other individuals. ${ }^{15}$ Annual revenue and net wealth was examined at the time of the relevant award or decision in the ISDS case. ${ }^{16}$

This approach to classification over-stated the role of small and medium enterprises and non-super wealthy individuals in ISDS. The categories used to identify small and medium - with annual revenues under USD100 million and USD1 billion respectively - were much more inclusive than what other measures would consider a small or medium enterprise. ${ }^{17}$ Likewise, some may consider individuals who have a net wealth below

\footnotetext{
${ }^{15}$ A more sophisticated analysis would treat annual revenue and net wealth as continuous variables; the classifications used here were simpler to code - especially in the case of net wealth - and thought sufficient to give an overall picture of past financial transfers.

${ }^{16}$ There were a few complicating cases, such as PacRim v El Salvador where ownership of the claim shifted from a small to a medium company in the course of the dispute (albeit without affecting the findings on ordered compensation because the case is ongoing) but for the most part the issue did not raise coding challenges. ${ }^{17}$ e.g. Organization for Economic Cooperation and Development, OECD SME and Entrepreneurship Outlook: 2005 (Paris: OECD), 17, citing EU definitions based on annual turnover of EUR10 million for small enterprises and EUR50 million for medium enterprises.
} 
USD100 million as still rich compared to owners of small and medium enterprises and other individuals. For the reasons, the findings may over-state the number of ISDS cases and financial transfers for small or medium-sized enterprises.

Where information was unavailable on a company's annual revenue, the company was classified as unknown. This separate category was used - instead of assuming, for example, that all such companies were small or medium - because, although some such companies appeared likely to be small or medium, others appeared to be potential holding companies where ultimate ownership could not be tracked. In contrast, where data was unavailable on an individual's net wealth, it was assumed that the individual was not super wealthy on the assumption that an individual worth USD100 million or more would be identifiable as such using standard online sources. In any event, as will be seen below, these classification issues appeared not to impact significantly the main findings of the paper.

Where there were multiple claimant nationalities (e.g. a claim both by a foreign company and by a subsidiary in the host state), the opposite nationality under the treaty or treaties under which the ISDS claim was brought was classified as the primary nationality. In a few cases, primary nationality was shared because the claim was brought under multiple treaties. The results of this coding allowed for incidental and approximate findings on apparent forum-shopping. That is, cases were noted as apparent forum-shopping cases where the largest or wealthiest owner of a claimant was based in, or (for individuals) had the nationality of, a country other than the primary nationality in the ISDS case. This was a loose approach to dealing with potential forumshopping in that it did not ask whether the company in the opposite state under the treaty had a substantial connection to that state or whether the ultimate owner's incorporation decision in the opposite state was made with express intent to facilitate an ISDS claim. Instead, forum-shopping as analyzed here captured (a) situations in which multinationals brought an ISDS claim from a jurisdiction within their network of corporate nationalities that was not their historical base of operations and (b) situations in which a super wealthy individual acquired the nationality of the opposite state by incorporating in that state. As will be seen, the clearest finding on forum-shopping that is directly relevant to financial transfers involves U.S. large or extra-large parent companies or U.S. super wealthy individuals that benefited from ISDS claims made by corporate claimants in the Netherlands.

Also for cases involving multiple claimants, each case was classified as having a single claimant size or wealth based on precedence for the largest or wealthiest ultimate owner of a claimant in the case. To illustrate, a claim both by a domestic company of the host state and by the foreign corporate owner of that company under the treaty, where 
the latter was ultimately owned by an extra-large parent company in a third state, was classified as a claim by the extra-large parent company. Alternatively, a claim by a medium company owned by a super wealthy individual was classified as a claim by that individual. In short, cases were coded based on the largest or wealthiest actor in the group of both claimants and ultimate owners of claimants. Although it did not arise in any of the cases coded here, precedence would have been given to classification as an extra-large or large company rather than as a super wealthy individual.

In light of these assumptions for cases involving multiple claimants, the data was reviewed to identify possible misrepresentations arising from situations in which multiple claimants of different sizes or wealth brought a claim and the case was classified as having been brought by the largest or wealthiest claimant in the group. In the great majority of such cases, the claimant group consisted of multiple companies in the same corporate group; multiple companies of the same size; multiple companies with one or more unknown companies alongside an large or extra-large company and apparently falling within the larger corporate group; multiple claimants with one or more unknown companies alongside an individual; multiple individuals including a super wealthy individual and one or more other individuals who were family members of or otherwise apparently related to the super wealthy individual; or multiple individuals none of whom appeared super wealthy. For all of these situations, in our view the coding assumptions for cases involving multiple claimants were appropriate.

However, there was one case - Abengoa v Mexico - where compensation was ordered and the coding assumptions appeared to risk misrepresenting the results. The claim was brought by an extra-large and an apparently unrelated large company but was coded as a claim by the extra-large company. The ordered compensation in the case was USD40 million (USD42 million including pre-award interest). We opted not to use an alternative coding approach - such as a 50-50 attribution of the claim between the two companies or attribution based on their relative size or ownership stake in the disputed assets because the case had little effect on the overall findings, the alternative coding approaches also had an arbitrary quality, the coding assumptions did not otherwise appear to raise concerns about misrepresentation, and, with the present disclosure, readers are able to evaluate and adjust the findings as they see fit.

Overall, the dataset had 292 cases coded for claimant size or wealth as of the spring of 2014 with data on outcomes, including amounts awarded, up to the spring of $2015 .{ }^{18}$ of

\footnotetext{
${ }^{18}$ Three cases were coded as NA (not applicable) for claimant size or wealth because it was difficult to identify a corporate or individual claimant based on the coding assumptions. They included cases brought by a state entity (Kaliningrad $v$ Lithuania), a series of irrigation districts and individuals (Bayview Irrigation $v$ Mexico), and a series of natural and juridical persons (CCFT $v$ USA). None of these cases led to a damages award; the first lacked public information and the other two were dismissed at the jurisdictional stage.
} 
these 292 cases, 253 were coded as having a jurisdictional outcome, i.e. a verifiable decision of the tribunal finding or not finding jurisdiction (other cases typically were ongoing or resolved before a jurisdictional outcome). Of these 253 cases, the tribunal declined jurisdiction in 52 cases and accepted jurisdiction in 201. Of these 201 cases, the tribunal did not find a violation of the treaty in 58 cases and found a violation in 162 (again, other cases typically were ongoing or had settled before a merits decision). Of these 162 cases, there were 89 in which an amount was confirmed to have been awarded (in four of these cases the amount was zero). Three of these 89 cases - the Yukos cases totalling USD50 billion in ordered compensation - swamped the other results and were relatively challenging to code for size or wealth of the claimant. For these reasons, these cases were presented separately in the paper. The remaining 86 cases constitute the dataset analyzed for ordered compensation due to ISDS.

Notably, two cases that led to awards were excluded from the 86 cases. CSOB v Slovakia was excluded because it was classified as a contract-based case although it fell close to the line and is arguably a contract-treaty hybrid. ATA $v$ Jordan was also excluded because it led to the remedy of an order that another arbitration could go ahead and so was difficult to quantify in terms of monetary value. Both cases involved claims by a large or extra-large company. For the record, I have provided the relevant data on the two excluded cases below. The main impact of the exclusion of these cases was to reduce the share of aggregate ordered compensation for extra-large companies from $76.8 \%$ (76.1\% including pre-award interest) to $73.5 \%$ (73.3\%).

\begin{tabular}{|l|r|r|r|r|r|}
\hline Case & $\begin{array}{r}\text { Claimant nationality } \\
\text { (with apparent } \\
\text { forum shopping (FS) } \\
\text { indicated) }\end{array}$ & $\begin{array}{r}\text { Corporation } \\
\text { or natural } \\
\text { person }\end{array}$ & $\begin{array}{r}\text { Claimant size } \\
\text { or wealth }\end{array}$ & Amount awarded & $\begin{array}{r}\text { Amount awarded + } \\
\text { pre-award interest } \\
\text { where available }\end{array}$ \\
\hline CSOB v Slovakia & Telgium) & Czech Republic (FS: & Extra-large & 1050 million & 1050 million \\
\hline ATA v Jordan & Turkey & $\mathrm{C}$ & Large & $\begin{array}{r}\text { NA - non monetary } \\
\text { order that other } \\
\text { arbitration can } \\
\text { proceed }\end{array}$ & $\begin{array}{r}\text { NA - non monetary } \\
\text { order that other } \\
\text { arbitration can } \\
\text { proceed }\end{array}$ \\
\hline
\end{tabular}

For the main analysis for this paper, ordered compensation at first-instance (i.e. not including set aside or annulment decisions) was compared to claimant size and wealth in all cases to the spring of 2014. Legal outcomes at the jurisdictional, merits, and combined stages of ISDS cases were also compared to claimant size and wealth. Finally, ordered compensation was compared to average ISDS costs for the disputing parties as estimated by other researchers. ${ }^{19}$ Findings on apparent forum-shopping were recorded incidentally, as discussed above.

${ }^{19}$ Gaukrodger and Gordon, above n 7. 